Multidisciplinary Journal of School Education Vol. 10, 2021/2 No. 20

ISSN 2543-7585 e- ISSN 2543-8409

DOI: $10.35765 / \mathrm{mjse} .2021 .1020 .08$

Submitted: 27.02 .2021

Accepted: 11.10 .2021

\title{
Arleta Suwalska
}

https://orcid.org/0000-0003-0713-8451

University of Lodz, Poland

e-mail: arleta.suwalska@now.uni.lodz.pl

\section{Ethical Education for Grades 1 and 2 in Finland from the Values Perspective}

\section{A man without ethics is a wild beast loosed upon this world. Albert Camus}

\begin{abstract}
The article addresses a key issue in curriculum policy, ethical education in Grades 1 and 2. The article uses the Finnish 2014 basic curriculum as the basis for a case study rooted in the humanities, philosophy, and the cultural sciences. The article explores what is embodied in this policy, especially the objectives of the subject of ethics in the curriculum. The article draws attention to the development of values through the curriculum in primary education in Finland and presents an overview of recent developments in values education in schools, taking curriculum research into account. The key part of the study is an analysis of the Finnish National Core Curriculum, principally those parts which involve secular ethics, as formulated by the Ministry of Education, and which emphasize the right of children to a good education and "to understand themselves, other people, the society, the environment, and different cultures" (National Core Curriculum, 2016, p. 15).

Keywords: ethical education, ethics, values, values in education, curriculum in primary education
\end{abstract}




\section{Introduction}

The main part of the study is an analysis of the Finnish National Core Curriculum, principally those parts which involve secular ethics, as formulated by the Ministry of Education, and which emphasize the right of children to a good education and "to understand themselves, other people, the society, the environment, and different cultures" (National Core Curriculum, 2016, p. 15). The article presents what is embodied in the objectives of the subject of ethics in the curriculum and which values and their strengths are developed through curriculum development in primary education in Finland.

\section{Secular Ethical Education or Religious Education in Finnish Elementary Schools}

The Finnish National Agency of Education prepared and launched a national core curriculum reform in the autumn of 2012. The process of curriculum reform was open and clear from the beginning, involving many individuals working collaboratively. Principals, teachers, representatives from ministries, teachers' unions, labor unions, parents, various ethnic groups, local education authorities, teachers, and researchers throughout the country worked together to design the reform and development of the core curriculum.

The substantial breadth and multidisciplinary nature of secular ethics is typically noted. The subject appears to be a substitute for religious education, based on philosophy and the social and cultural sciences. Secular ethics takes a multidisciplinary perspective, presenting similarities to integrative models of religious education (Tomperi, 2003). In 2015, secular ethics was studied by $5 \%$ of comprehensive school students, Evangelical Lutheran religion by $91 \%$, and other religions by $4 \%$ (Statistics Finland, 2014). Today, secular ethics classes are also open to students with religious affiliations other than Lutheran. Moreover, Lutheran students do not have the right to attend secular ethics lessons. 
Debates concerning religious diversity and the ways education should be developed in both religious and non-religious worldviews have played a central role in the works of Robert Jackson (2014) and Siebren Mediema (2014). According to Jackson, religious education has never been presented as widely as it is now (Jackson, 2012). Non-religious and religious perspectives in Finland are both taken into consideration by the separative education model. On this basis, the religious education of learners is organised according to their religious beliefs, with Lutheranism and alternative religions being the fundamental basis of organisation.

Students who are not a part of a religious community study secular ethics. Furthermore, the subject of secular ethics in Finland represents an autonomous improvement over other nations' initiatives. It is generally presented as an originally Finnish subject (Niniluoto, 1995). Secular ethics lessons appeared in the 1920s, when it was necessary to provide the "history of religion and ethics" for students who were non-affiliated in terms of religious education (Saine, 2000). The beginnings of the current subject of secular ethics followed in 1985 with the inauguration of a new subject, called elämänkatsomustieto in Finnish. This word has no straightforward translation and has been interpreted in many ways, including "education in life stance," "philosophy of life," and "life questions and ethics." This article uses the name "secular ethics" to distinguish it from ethics - which is described as a field of philosophy - and from religious education (AarnioLinnanvuori, 2013).

The range of secular ethics education includes four main content areas that were universal in the national comprehensive school curricula for 2004: "human relations and ethical development," "self-knowing and cultural identity," "society and human rights," and "the human being and the world."The basic objectives introduce not only critical skills for ethical action, but also studies on tolerance, justice, and sustainable development. The objectives for the first five grades include knowledge about cultures and human worldviews. The National Curriculum (2004) stipulates that instructing students in cultural literacy, in addition to interactive and self-expressive intercultural capabilities, is the fundamental aim of this aspect. 
The National Curriculum of 2014, in effect since autumn 2016, has been restructured, but it retains the objectives of the curriculum from 2004.

According to Niiniluoto (1995), the definition of secular ethics education concerns a personal worldview - including ethics, values, and views about the world - within an epistemological view which reveals how students recognize and acquire knowledge. The priority of secular ethics education is to guide and support students' growth and development, specifically their worldviews and philosophies of life. The subject of secular ethics is regarded as non-confessional, since its aim is neither to present nor to socialize students into specifically organized worldviews. However, Poulter et al. (2015) disputed the claim that the secular framework is neutral, since education has been always culturally and morally loaded. According to Tomperi (2003), the beginnings of secular ethics education are based on knowledge and meanings which are close to us as human beings, irrespective of non-religious and secular worldviews. The subject of secular ethics is based on values such as democracy, human rights, non-violence, and positive multiculturalism (Tomperi 2013).

\section{Research Questions and Methodology}

In order to present secular ethics education from a Finnish perspective, I formulated the following research questions: What values in Grades 1 and 2 are included in the Finnish secular ethical education curriculum? What are its strengths?

The main component of my study was an analysis of the Finnish National Core Curriculum for Basic Education 2014, especially those parts covering the content to be taught, which are applicable to all schools in Finland. As I mentioned previously, the analysis of the curriculum began with a review of the literature on values in teaching and secular ethics. The next step was to concentrate on the curriculum and to identify how issues of secular ethics were addressed. I also used the curricular guidelines, differentiations, and support for elementary schools in Grades 1 and 2 with content areas. 
I employed the problem method, along with critical discourse analysis and the study of documents concerning educational change and the study of discourses in political rhetoric. I collected data concerning specific areas of political activities and "macro-themes of discourse" (Wodak \& Krzyżanowski, 2008, p. 156). The problem method derives from an educational phenomenon which is placed in time and related to society. From this perspective, it is necessary to contrast different views, regularities, and principles. Discourse analysis was conducted using meanings which were usually contextual. In this light, this article uses discourse not only language and its meanings, but also conventions and codes which are typical of particular societies and anchored in their cultures and history (Hammersley, 2013). Moreover, discourses are "social texts, ... particular signifying practices of a given group that are both constituted by and constitutive of the discourse field in which members of the group live and function" (Elbaz, 1990, p. 15).

In this article, I aimed to use primary rather than secondary sources, appearing in different places and at different times. I chose representative documents and analyzed the meanings they presented along with their intended and perceived contexts. Resources available from the University of Helsinki library were assessed, which was the most crucial stage. The next step was to choose materials for the final analysis. The sample materials which were the most representative and which provided the greatest support were used for this article.

\section{Values and Education}

The continuity of values in the contemporary era is significant due to the technological advances and changes from globalization. According to Berkowitz (1995) and Oser (1996), values investigate subjective judgments (attitudes) and behavior. The moral imperatives of a society are determined and conveyed to the individuals residing within it based on the values that develop in society from honest viewpoints and principles. Berkowitz (1996) added that there is no need to have many values 
to develop morality in peoples'judgments and actions; people need only such central values as justice and well-being. Berkowitz (1997) named these regulative values due to their useful characteristics or "meta-morals."

Values and education are currently being discussed throughout the Western world and in Asia (Stephenson et al., 1998). Different terms are used around the world to refer to tradition and the theoretical position of values (Veugelers, 2000). We read about "values education,"'character education," "moral education," "personal and social education," "citizenship education,"'civic education," "'religious education", "moralogy," and "democratic education," especially in the English-language literature. Scientific publications in Finland more often employ the term "moral education" or "ethics." Publications from the USA and Singapore use the term "character education," whereas in Scotland and England "value education" is common (Munn, 1995; Halstead \& Taylor, 1996). In the European context it is usually "civic education" (Starkey, 1991).

Values have various dimensions and they are embedded in the curriculum. They are often used to design a school's mission (National Core Curriculum, 2016, p. 19). Seen in this perspective, values are like constructs: in adopting them, people decide what is good and what is bad, how they solve their problems, and what they believe in. Values "are not personal preferences based on taste; they are judgements based on more or less explicit and systematic ideas about how a person relates to his/her environment" (Veugelers \& Vedder, 2003, p. 379). Teachers and students have their sets of values, which "collaborate" in education. Teachers have the will to influence the students' values and the moral functioning of the school, which is perceived as a learning organization.

\section{The Values of Basic Education and its Roots in Philosophy, the Humanities, and Social Sciences in the Finnish National Core Curriculum for Basic Education, 2014}

Finland's national curriculum directs the country's education system by defining values and objectives for all Finnish elementary schools. 
There are no school inspections in Finnish schools. The curriculum designates the main objectives and goals for school subjects and motivates teachers to use new learning methods in project-based and collaborative learning. The curriculum may be construed freely by every basic school, even though prior establishment of the principal frameworks has occurred. The National Core Curriculum for Basic Education 2014 in Finland contains 508 pages, 100 pages of which deal with school values, goals, and principles. The rest of the document presents the syllabi of school subjects.

Figure 1. Values in Basic Education in Finland (National Core Curriculum, 2016, pp. 15-17)

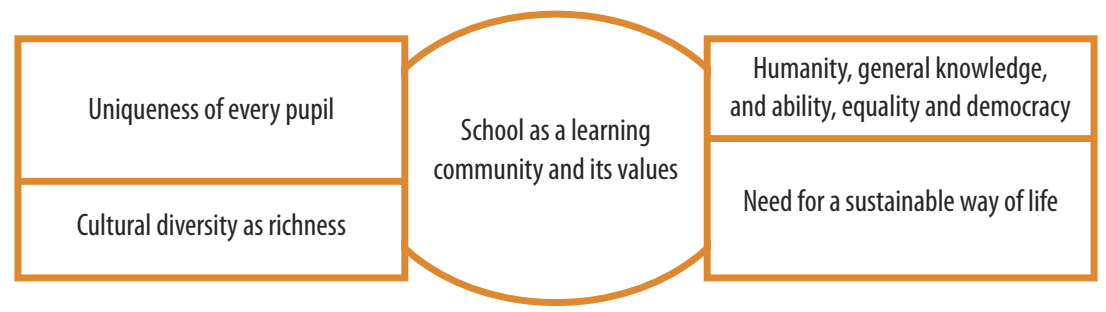

According to the document (National Core Curriculum, 2016, p. 15), each child is unique and valuable. It stresses the child's uniqueness and right to improve their skills as a human being and as part of a democratic society. To accomplish this, pupils need not only individual support, but also encouragement and the experience that they are valuable and being heard in their society. The core curriculum emphasizes the need for students to work together "to advance the functioning and welfare of the community" (p. 15). It stresses the right of each child to a good education. Furthermore, learning is perceived as a process which helps students build their "identity, understanding of humanity, worldview, and philosophy of life and to find their place in the world. At the same time, they come to understand themselves, other people, the society, the environment, and different cultures" (National Core Curriculum, 2016, p. 15). Taking all 
this into account, basic education designs and strengthens the conditions for lifelong learning on the part of each student.

In the contemporary world, values education is emphasized due to various forms of media, the global network, social media, and students' relationships, all of which contribute to the value system presented above. It is suggested that, during lessons in Finnish schools, discussions should be conducted with students concerning the values that enable them to build their own life values. As a result, students perceive a variety of values in their lives and are able to think about them critically. All in all, schools support students in building their systems of values. Students' holistic well-being in basic education is built through cooperation between the values promoted in schools and in their homes. Open-mindedness and a respectful attitude on the part of teachers towards various religions and worldviews constitute the root of constructive schooling, cooperation, and interaction.

Apart from philosophy and the right of each child to a good education, the core curriculum emphasizes support for each child in their growth as a human being. It stresses the need to aspire to "truth, goodness, beauty, justice, and peace" (p. 16). Every child's development is shaped by sympathetic and ethical disputes, in addition to the right to advocate for sound reason, according to the humanistic standpoint.

In this light, each student and each community are capable of making decisions following ethical reflections. The document emphasizes the importance of the ethical and aesthetic perspective in guiding students towards a realization of what is valuable in their lives. Consequently, for an educated individual in Finland, the news, surroundings, other individuals and one's personal life are viewed in a way that informs the understanding of one's environment They are able to take action and to show respect to other people.

It should be mentioned that "respect for human life, human rights, and human dignity" are the humanistic roots of basic education in Finland. Education contributes to the promotion of well-being in a democratic society and promotes "economic, social, regional, and gender equality"(p. 16). In Finland, the idea that education does not lead to any philosophical, 
political, or religious commitments is emphasized. 'Richness' is how the document views cultural diversity, which makes edu-cation crucial. The core curriculum emphasizes "cultural diversity as richness." Education in Finland is based on "a diverse Finnish cultural heritage" (p. 16). Taking all this into account, students are supported in building their own"personal cultural identities" and their gradual development as valuable agents capable of participating in the culture. Primary education reinforces students' creativity and contributes to the promotion of interactions between cultures in the light of omnipresent sustainable development. Moreover, students from different cultures and linguistic backgrounds understand different customs and beliefs. They are capable of recognizing the circumstances and life situations of others. In connection with this issue, genuine intercultural interaction and communality is created as a result of study "across the boundaries of languages, cultures, religions, and beliefs" (p. 16).

In addition to the uniqueness of each child and the right to a good education, the writers of the national core curriculum took into account "humanity, general knowledge and ability, equality, and democracy" (p. 16). The document stresses the need to support each child's growth and to contribute to the child's "truth, goodness, beauty, justice, and peace" and it emphasizes the conflicts between students' aspirations and the realities of their lives. Students' ability to resolve these conflicts ethically and their courage in defending what is good constitute parts of their general knowledge and ability, which in turn enable them to make decisions dependent on ethical thinking and their capacity for putting themselves in another student's place. The guide to ethical perspectives and esthetics teaches students what is valuable in their lives. "General knowledge and ability manifest themselves in our attitudes towards ourselves, other people, the environment, and information, in the ways we act, and in our willingness to take action" (p. 16). An educated person strives to behave properly and to show respect for themselves, other people, and the environment. They are able to manage information in a critical manner. Efforts at self-regulation and taking responsibility for one's own development and well-being are also part of general knowledge and skills. In this light, it is emphasized that basic education relies on 
respect for human life and rights in order to promote well-being and democracy. The basic education curriculum is grounded in economic, social, regional, and gender equality and equity.

Viewed from the perspective of the curriculum, basic education in Finland affirms sustainable development with eco-social knowledge. Humans, as a part of nature, rely on the vitality of ecosystems and reflect on the "necessity of a sustainable way of living." Eco-social knowledge contributes to the creation and understanding of sustainable ways of living and the inviolability of human dignity. It supports the renewal of ecosystems through students' ability to practice the sustainable use of natural resources, especially with regard to climate change. Elementary school students discuss conflicts between different styles of consumption and the country's production, in the interests of a sustainable future. These discussions broaden the students' understanding and horizons and teach them to value cross-generational responsibility.

\section{Values in the Tasks of Ethical Education in Grades 1 and 2 with Content Areas C1-C4}

There is no doubt that the Finnish National Core Curriculum for Basic Education 2014 incorporates the underlying values of basic education and states that its main task is to promote "pupils' ability to pursue a good life" (p. 148). This appears to be the strong point of the curriculum, also supported by students' obligation to reshape and create experiences during ethics lessons, to attempt to understand different cultures, and to share with each other activities which produce meaning in school and outside of school. Some schools even encouraged their students to read the drafts of the core curriculum and to assess the text and present their feedback. The subject of secular ethics is based on values such as democracy, human rights, non-violence, and positive multiculturalism (Tomperi, 2013). The term "values" is used in the present paper to refer to the principles and common beliefs which serve as basic guides to behavior and to standards which are perceived as good or desirable. 
Another positive assumption is associated with this investigation: that ethics should guide students towards their own independence, openmindedness, and participation in a democratic Finnish society. On the other hand, "critical thinking is understood as a self-correcting activity that seeks reasons and perceives connections, and is sensitive to different situations" (p. 149). Let us first take a closer look at Grades 1 and 2. The teaching and learning of ethics in basic education is concentrated on cooperation and skills (thinking and learning) in education. A major benefit at this level of education is the provision of support for each student in terms of healthy self-confidence and a positive working self-image. In order to understand this more profoundly and to perceive existing strengths and gaps, we should analyze the objectives of ethics instruction in Grades 1 and 2 presented in the National Core Curriculum.

The first objective is to "guide the pupil to listen to the opinions and thoughts of other pupils"; the second one is "to encourage the pupil to express his or her thinking and feelings in different ways"; the third objective is to "guide the pupil to appreciate his or her own and others' thinking and to support the development of the pupils' ability to ask questions and present justified arguments" (National Core Curriculum, 2016, p. 149). It seems reasonable to assume that the succeeding objectives are to "guide the pupil to recognize the causes and consequences as well as the ethical dimensions of the everyday situations he or she encounters" and to "encourage the pupil to reflect on goodness and the difference between right and wrong" (p. 149). Still other objectives are to "guide the pupil to learn about different customs in his or her surroundings, to guide the pupil to understand the foundations of communal life, and to guide the pupil to respect and value his or her own environment and nature" (p. 149). As a result, Finnish teachers prepare students to function well in a democratic society and to some extent teach them how to be a "good citizen." According to Veugelers (2001), democratic citizens take a critical social approach towards their skills, which are linked to their manner of solidarity with other students, especially in a multicultural society. It seems reasonable to assume that Finnish students are taught how to participate actively in society and to respect existing differences between 
citizens. On the other hand, teachers can never be certain about the consequences of the decisions students make in their own lives.

To reinforce the meaning of the new curriculum, teaching on this level includes key Content Areas $\mathrm{C} 1$ and $\mathrm{C} 2$, which are related to the objectives of ethics presented above. As a result, the content areas are used to form units for each grade. The pupils' experiences, ideas, and thoughts "are taken into account in the selection of content and in more detailed discussion of it" (National Core Curriculum, 2016, p. 149). I observe that these sets of Finnish school values are embedded in the curriculum and are perceived as signposts to teachers, who are obliged to include them in their teaching practice. This can be a plus or a minus for teachers and their methods of teaching, depending on their personalities. Some teachers prefer such solutions - others do not.

According to the National Core Curriculum for Basic Education 2014, in Content Area C1, concerning reflections on a good life, each student learns conversational skills through the respectful process of listening to others. Students are taught how to recognize the difference between good and bad and right and wrong, how to understand human goodness, and the meaning of friendship. Content Area C2 - different ways of life - offers answers to the question, "Who am I?" and explains different lifestyles to the student in the "context of his or her own family and cultural background" (National Core Curriculum, 2016, p. 150). The appraisal of issues and what is negative or positive rests crucially on one's cognitive abilities. In this light, Oser (1996) used the term moral discourse, which involves an interactive discussion concerning issues of justice, with the purpose, according to Oser, of teaching children how to develop their own opinions while also taking the opinions of others into consideration.

The National Core Curriculum for Basic Education 2014 also includes Content Area C3, which presents the content of communal life, presenting its foundations via the meanings of rules, trust, honesty, and fairness in various life situations. Viewed from the perspective of document analysis, it can be said that students study the status and rights of children. Content Area C4 - nature and a sustainable future - concerns the exploration of different forms of life on Earth and research on the finite nature 
of human life, along with examinations of choices and actions which students view as helping them to "seek meaningful experiences related to nature" (p. 150). I suggest that this part of curriculum fits within social constructivism in cognitive psychology, where efforts are made in the production of knowledge (Prawat, 1998). As a result, the production of knowledge is perceived as a process of personal meaning; if values are linked to this knowledge, personal meaning is more significant. The conclusion is that this process can reinforce students' ability to use sets of values in their lives.

Concerning the curriculum, Buzelli (1992) suggested that the formulation of moral intelligence in children is vitally shaped in the two years following birth. In accordance with Dunn (1988), emotional and social development of learners is intimately linked to moral development. Truth, composure, security, contentedness, justice, freedom, equality and love are particular values in this regard. Children learn about values not only in their homes, but from their peers, the media, and their local community. Children arrive at school with a catalogue of various values from their experiences at day-care centers or kindergarten. Consequently, elementary schools supplement the values children have already acquired and develop values that are omnipresent in society.

According to the National Core Curriculum for Basic Education 2014, it is valid to use working methods which contribute to the creation of a safe, psychologically, and socially open learning environment. The core curriculum presents objectives such as culture, worldview, and ethics, which reinforce students' self-efficacy in providing guidance and support. Efforts are made to foster a physical learning environment, in terms of both teaching and learning. "Inquiry-based group discussions led by the teacher are enriched with functional activities, fairy tales, stories, play, music, visual arts, and drama" (National Core Curriculum, 2016, p. 150). To sum up this discussion, the subject of ethics supports students' opportunities to understand and identify with various worldviews. Certainly, the choice of varied teaching methods by Finnish ethics teachers is the key to success in their individual approach to pupils. It seems reasonable to assume that learning at this level in Finland is perceived as a process 
that helps students to build their "identity, understanding of humanity, worldview, and philosophy of life and to find their place in the world."

\section{Conclusion}

Finnish teachers, by using sets of school values embedded in the curriculum, teach students how to actively participate in society and to respect differences between citizens, especially in a multicultural society. The article presented the objectives of the subject of ethics in the Finnish elementary education curriculum and the strengths of the values it develops.

The National Core Curriculum for Basic Education 2014 stresses the right of each child to a good education. The National Core Curriculum (2016, p.15) defined perspective learning as a procedure through which learners are able to discover their location in the world, their life philosophy, world perspective, comprehension of humanity and their identity.

In this light, students are taught how to recognize the difference between good and bad, how to to understand human goodness, and the meaning of friendship.

Every child's development is shaped by sympathetic and ethical disputes, in addition to the right to advocate for sound reason, according to the humanistic standpoint. Students' holistic well-being is strengthened in basic education through cooperation between the values promoted in schools and in their homes. As a result, students are capable of making decisions following ethical reflection. The document emphasizes the importance of the ethical and esthetic perspective in guiding students towards a realization of what is valuable in their lives. As a result, students are able to take action and to show respect to other people.

In Content Areas $\mathrm{C} 1-\mathrm{C} 4$, each student learns conversational skills through the respectful process of listening to others, answering the question, "Who am I?," and understanding different lifestyles in the "context of his or her own family and cultural background" (National Core Curriculum, 2014, p. 150). In this light, the student not only recognizes the meanings 
of rules, trust, honesty, and fairness in various life situations, but also explores different forms of life on Earth and research into the finite nature of human life.

Viewed from the perspective of the curriculum, basic education in Finland affirms sustainable development with eco-social knowledge, which contributes to the creation and understanding of sustainable ways of living, the inviolability of human dignity, and the sustainable use of natural resources, especially with regard to climate change. Elementary school students discuss conflicts between different styles of consumption and the country's production in order to learn to value cross-generational responsibility. 


\section{References}

Aarnio-Linnanvuori, E. (2013). Environmental Issues in Finnish School Textbooks on Religious Education and Ethics. Nordidactica, 1, 131-157.

Berkowitz, M. W. (1995). The Education of the Complete Moral Person. Gordon Cook Foundation.

Berkowitz, M. W. (1996). The "Plus One" Convention Revisited and Beyond. Paper presented at the Annual Meeting of the Association for Moral Education, Ottawa, Canada.

Berkowitz, M. W. (1997). Integrating Structure and Content in Moral Education. Paper presented at the Annual Meeting of the American Educational Research Association, Chicago, IL.

Buzzelli, C. A. (1992). Young Children's Moral Understanding: Learning About Right and Wrong. Young Children, 47(6), 47-53.

Dunn, J. (1988). The Beginnings of Social Understanding. Harvard University Press. Elbaz, F. (1990). Knowledge and Discourse: The Evolution of Research Into Teachers' Thinking. In C. Day, M. Pope, \& P. Denicola (Eds.), Insights Into Teachers' Thinking and Practice (pp. 15-42). Falmer.

Finnish National Agency of Education. (2016). National Core Curriculum for Basic Education 2014. Juvenes Print-Suomen Yliopistopaino Oy.

Finnish National Board of Education. (2004). National Core Curriculum for Basic Education. Retrieved December 12, 2020 from

http://www.oph.fi/english/curricula_and_qualifications/basic_education.

Halstead, J. M., \& Taylor, M. J. (Eds.). (1996). Values in Education and Education in Values. Falmer.

Hammersley, M. (2013). What is Qualitative Research? Sage.

Jackson, R. (2012). European Developments. In L. Barnes (Ed.), Debates in Religious Education (pp. 168-179). Routledge.

Kohlberg, L. (1971). From Is to Ought. In T. Mischel (Ed.), Cognitive Development and Epistemology. (pp. 151-235). Academic Press.

Königsberger, G., \& Kubarth, L. (2013). Religious Education in Austria. In D. Davis \& E. Miroshnikova (Eds.), Routledge International Handbook of Religious Education (pp. 33-39). Routledge.

Mediema, S. (2014). From Religious Education to Worldview Education and Beyond: The Strength of a Transformative Pedagogical Paradigm. Journal of the Study of Religion, 27(1), 82-103. 
Munn, P. (1995). Values Education in Scottish Schools. In D. Vanveen \& W. Veugelers (Eds.), Vernieuwing van leraarschap en lerarenopleiding (pp. 67-77). Garant.

Niiniluoto, I. (1995). Elämänkatsomustiedon filosofisia ongelmia [Philosophical Problems of Secular Ethics]. In P. Elo \& H. Simola (Eds.), Arvot, hyveet ja tieto (pp. 142-148). Feto.

Oser, F. K. (1986). Moral Education and Values Education: The Discourse Perspective. In M. C. Oser, F. K. (Eds.), Moral Perspectives on Teaching, Review of Research in Education, 20, 57-127.

Oser, F. K. (1996). Attitudes and Values, Acquiring. In E. De Corte \& F. E. Weinert (Eds.), International Encyclopedia of Developmental and Instructional Psychology (pp. 489-491). Pergamon.

Poulter, S., Riitaoja A. L., \& Kuusisto A. (2015). Thinking Multicultural Education "Otherwise": From a Secularist Construction Towards a Plurality of Epistemologies and Worldviews. Globalisation, Societies, and Education, 14(1), 1-19. DOI: $10.1080 / 14767724.2014 .989964$

Power, F. C., \& Power, A. M. R. (1992). A Raft of Hope: Democratic Education and the Challenge of Pluralism. Journal of Moral Education, 21, 193-205.

Prawat, R. S. (1998). Current Self-Regulation Views of Learning and Motivation Viewed Through a Deweyan Lens. American Educational Research Journal, 35, 199-226.

Saine, H. (2000). Uskonnonopetus Suomen oppivelvollisuuskoulussa 1900-luvulla [Religious Education in Finnish Compulsory Schooling in the 20th century] (Unpublished doctoral dissertation). University of Turku.

Salmenkivi, E. (2013). Katsomusopetuksen kehittäminen [The Development of Religious Education]. Niin \& Näin, 76(1), 87-89.

Starkey, H. (Ed.). (1991). Socialisation of School Children and their Education for Democratic Values and Human Rights. Swets \& Zeitlinger.

Statistics Finland. (2015). School Subject Choices 2014. Helsinki.

Stephenson, J., Ling, L., Burman, E., \& Cooper, M. (1998). Values in Education. Routledge.

Tomperi, T. (2003). Elämänkatsomustiedon identiteetti opetussunnitelmassa [The Identity of Secular Ethics in the Curriculum]. In P. Elo, K. Heinlahti, \& M. Kabata (Eds.), Hyvän elämän katsomustieto (pp. 10-31). Feto. 
Tomperi, T. (2013). Uskonto, kulttuuri, elämänkatsomus, filosofia [Religion, Culture, Worldview, Philosophy]. Niin \& Näin, 76, 91-93.

Veugellers, W. (2000). Different Ways of Teaching Values. Educational Review, 51, 37-46.

Veugellers, W. (2001). Teachers, Values, and Critical Thinking. In S. R. Steinberg (Ed.), Multi/Intercultural Conversations (pp. 199-215). Peter Lang.

Veugellers, W., \& Vedder, P. (2003). Values in Teaching. Teachers and Teaching Theory and Practice, 9(4), 377-389.

https://www.researchgate.net/publication/46692085_Values_in_Teaching

Wodak, R., \& Krzyżanowski, M. (2008). Qualitative Discoursive Analysis in the Social Sciences. Palgrave Macmillan. 